\title{
The relation between active smoking and colposcopical and cytological findings in the cervix uteri
}

\author{
Muhad A. Ali ${ }^{1 *}$, Safa K. Salman ${ }^{1}$, Rana M. Issa ${ }^{2}$ \\ ${ }^{1}$ Department of Obstetrics and Gynecology, Faculty of Medicine, Tishreen University, Lattakia, Syria
}

${ }^{2}$ Department of Pathology, Faculty of Medicine, Tishreen University, Lattakia, Syria

Received: 02 July 2020

Accepted: 18 July 2020

*Correspondence:

Dr. Muhad A. Ali,

E-mail: maali19912016@gmail.com

Copyright: ( $)$ the author(s), publisher and licensee Medip Academy. This is an open-access article distributed under the terms of the Creative Commons Attribution Non-Commercial License, which permits unrestricted non-commercial use, distribution, and reproduction in any medium, provided the original work is properly cited.

\section{ABSTRACT}

Background: All types of smoking have been associated with cervical neoplasia, and the long-term of use tobacco products and intensity of smoking could influence cervical carcinogenesis. The aim of this study is to identify the association between smoking and the presence of colposcopical and cytological abnormalities in cervix uteri.

Methods: An observational case-control study was applied on 100 patients to investigate this relationship. The patients were divided into two groups, smokers' group (70) cases and nonsmokers' group (30) cases. All of the patients have been submitted to colposcopy and Papanicolaou smear. Comparison of colposcopic and cellular findings between both groups was done.

Results: Authors found that there was a significance difference in the rate of abnormal colposcopical findings between two groups. This rate in smokers' sample was $45.7 \%$ and in the second was $26.7 \%$ with p-value $=0.04$. Additionally, there was no significance difference in the rate of abnormal cytological findings. This rate in smokers' group was $32.9 \%$ whereas in the second was $23.4 \%$ with p-value $=0.6$.

Conclusions: This study data suggests that smoking increases abnormalities in papanicolaou smear and colposcopy.

Keywords: Cervical cancer, Colposcopy, Papanicolaou smear, Smoking

\section{INTRODUCTION}

Cervical cancer is a common gynecological cancer with a higher incidence in developing countries than in developed countries. ${ }^{1}$ Worldwide, cervical cancer ranks fourth for both incidence and mortality, the GLOBOCAN project (global cancer statistics) of cancer incidence and mortality produced by the International agency for research on cancer estimated that there were 569847 new cases of cervical cancer and 311365 deaths from cervical cancer in 2018. ${ }^{2}$ In Syria, the 2019 Statistics estimated that every year 259 women are diagnosed with cervical cancer and 190 die from the disease, so cervical cancer ranks as the $12^{\text {th }}$ most frequent cancer among women in Syria and the $9^{\text {th }}$ most frequent cancer among women between 15 and 44 years of age. ${ }^{3}$ Winkelstein Jr in 1977 was the first to put the hypothesis that smoking is a risk factor for cervical cancer. ${ }^{4}$ Since then, the influence of tobacco on cervical carcinogenesis has been a matter of scientific debate to the International agency for research on cancer (IARC) placed cigarette smoking in Group 1, i.e., carcinogenic to humans and has concluded that there is sufficient evidence for a relationship between cigarette smoking and the risk of squamous cell carcinoma of the cervix. $^{3}$ Although human papillomavirus (HPV) is a major risk factor of cervical cancer, the co-factors such as cigarette smoking, long-term oral contraceptive (OC) use and high parity also have been established as risk factors in cervical carcinogenesis. ${ }^{5}$ The International collaboration of epidemiological studies of cervical cancer evaluated the risk of cigarette smoking and found that current smoking increased the risk of cervical squamous cell carcinoma, but not that of adenocarcinoma. The risk increases up to 3 -fold by the 
increasing number of cigarettes smoked per day and years smoked. ${ }^{5}$ Water pipe is another type of smoking that is very common in middle east and nowadays it is spread globally, but data on the health impacts of it is limited and authors need more researches to find out how harmful it is. ${ }^{6}$ The aim of the study is to evaluate the association between active smoking in both types (cigarette-water pipe) and colposcopical and cellular abnormalities in cervix uteri. Additionally, identify the effect of long- term smoking and the intensity of it based on these changes.

\section{METHODS}

Following approval by authors institutional ethics committee, an observational study was done for patients attending the clinic of obstetrics and gynecology at Tishreen University hospital from October 2018 to December 2019.

\section{Inclusion criteria}

- This study inclusion criteria were all women (other than the virgins) who are aged between 18-65 years and didn't have gynecological symptoms.

\section{Exclusion criteria}

- Included women with total hysterectomy and those who were diagnosed with invasive cervical cancer.

At first, the procedures (which were done) were explained to patients enrolled in the study and a written informed consent was taken from them. All the patients were recommended abstaining sexual intercourse for the previous 24 hours. A detailed clinical history was taken from the patients with an emphasis on the sexually transmitted diseases, contraceptive methods used. In this study, the greatest importance was given to questions about the patient's habits in terms of being a smoker or non-smoker, in addition to detailing the type of smoking (cigarettes-water pipe) and the duration of smoking in years and the intensity of smoking (cigarette/per day bong of water pipe/per week). After a history was taken, authors started to examine the vulva then authors performed an ectocervix and endocervix smear. After that, authors performed a colposcopy by applying acetic acid $5 \%$ on cervix uteri. Authors fixed the slides of smears with ethanol $95 \%$ and sent them to the department of pathology where the smears read according to the Bethesda system 2014.

\section{Statistical analysis}

This study is an observational (case-control study). Data was fed to the computer and analysed using IBM SPSS software. Quantitative data were described using median, minimum and maximum. Qualitative data were described using recurrence and percentages. Authors used chisquare test to study the relationships between qualitative variables and considered the results statistically significant with p-value $<5 \%$.

\section{RESULTS}

The age of the patients in the research sample ranged between 18 to 63 years, and average age was 39.2 \pm 9.4 years. The research sample was divided into two groups, the first group included 70 patients from both types of smokers (cigarettes smokers and water pipe smokers), where the smoking period ranged between 2-30 years and the average number of smoking years were 13.5 \pm 7.7 years. The second group included 30 patients from nonsmokers. In the first group $38(54.3 \%)$ had a normal colposcopical finding and $32(45.7 \%)$ had abnormal findings, whereas in the second group $22(73.3 \%)$ had normal findings in colposcopy and only $8(26.7 \%)$ had abnormal ones (Table 1).

Table 1: Distribution of colposcopical findings between two groups.

\begin{tabular}{|c|c|c|c|}
\hline $\begin{array}{l}\text { Colposcopical } \\
\text { findings }\end{array}$ & $\begin{array}{l}\text { Smokers } \\
\text { group }\end{array}$ & $\begin{array}{l}\text { Nonsmokers } \\
\text { group }\end{array}$ & $\begin{array}{l}\text { p- } \\
\text { value }\end{array}$ \\
\hline Normal & $38(54.3 \%)$ & $22(73.3 \%)$ & \multirow{2}{*}{$0.04 *$} \\
\hline Abnormal & $32(45.7 \%)$ & $8(26.7 \%)$ & \\
\hline
\end{tabular}

Table 2: Distribution of cytological findings between two groups.

\begin{tabular}{|llll|}
\hline $\begin{array}{l}\text { Cytological } \\
\text { findings }\end{array}$ & $\begin{array}{l}\text { Smokers } \\
\text { groups }\end{array}$ & $\begin{array}{l}\text { Non-smokers } \\
\text { group }\end{array}$ & $\begin{array}{l}\text { p- } \\
\text { value }\end{array}$ \\
\cline { 1 - 3 } Normal & $47(67.1 \%)$ & $23(76.7 \%)$ & $0.6^{*}$ \\
\hline Abnormal & $23(32.9 \%)$ & $7(23.4 \%)$ & \\
\hline
\end{tabular}

*No statistically significant at $\mathrm{p} \leq 0.05$.

Table 3: Distribution of colposcopical and cytological findings in smokers group according to duration of smoking.

\begin{tabular}{|c|c|c|c|}
\hline \multicolumn{4}{|c|}{ Duration of smoking (years) } \\
\hline & $10 \geq$ & $10<$ & p-value \\
\hline \multicolumn{4}{|c|}{ Colposcopical findings } \\
\hline Normal & $19(73.1 \%)$ & $19(43.2 \%)$ & \multirow{2}{*}{$0.01 *$} \\
\hline Abnormal & $7(26.9 \%)$ & $25(56.8 \%)$ & \\
\hline \multicolumn{4}{|c|}{ Cytological findings } \\
\hline Normal & $21(80.8 \%)$ & $26(59.1 \%)$ & \multirow{2}{*}{$0.04 * *$} \\
\hline Abnormal & $5(19.2 \%)$ & $18(40.9 \%)$ & \\
\hline
\end{tabular}

With regard to cytological findings, in first group 47 $(67.1 \%)$ had normal smears and $23(32.9 \%)$ had abnormal findings, whereas in the second group $23(76.7 \%)$ had normal smears and 7 (23.4\%) had abnormal ones (Table 2). To further verify from effects of smoking on colposcopical and cytological findings in the cervix uteri, authors divided the smoker's sample into two categories 
according to the duration of smoking (mean of the number of the smoking duration were 10 years). When the duration more than 10 years, the abnormal colposcopical and cytological findings were $(56.8 \%$, $40.9 \%$ ) respectively (Table 3 ). For more affirmation authors evaluated the intensity of smoking with this study variables after dividing smokers' sample into two categories according to type of smoking. The abnormal colposcopical findings were two when the number of cigarettes less than five per day, whereas they're up to nine when the number of cigarettes were more than 14 per day (Table 4). Also, the abnormal cytological findings were five when the number of bongs (water pipes) less than four per week while them up to eight when the number of bongs were more than six (Table 5).

Table 4: Distribution of colposcopical findings in smokers group according to intensity of smoking.

\begin{tabular}{|c|c|c|c|c|c|c|}
\hline \multirow{2}{*}{$\begin{array}{l}\text { Colposcopic } \\
\text { findings }\end{array}$} & \multicolumn{3}{|c|}{ Cigarettes (Cigarette per day)* } & \multicolumn{3}{|c|}{ Water pipes (Bong per week)** } \\
\hline & 1-4 & $5-14$ & $14<$ & $1-3$ & 4-6 & $6<$ \\
\hline Normal & - & $1(50 \%)$ & $10(52.6 \%)$ & $10(47.6 \%)$ & $12(100 \%)$ & $4(28.6 \%)$ \\
\hline Abnormal & $2(100 \%)$ & $1(50 \%)$ & $9(47.4 \%)$ & $11(52.4 \%)$ & - & $10(71.4 \%)$ \\
\hline p-value & $0.04 * * *$ & & & $0.01 * * *$ & & \\
\hline
\end{tabular}

*SMET NASUTION classification was used to divide this category into three groups according to the number of cigarettes smoked per day ${ }^{7}, * *$ this category was divided into three groups according to the mean of the number of hookah heads (Bong smoked per week), ${ }^{* * *}$ statistically significant at $\mathrm{p} \leq 0.05, * * * *$ statistically significant at $\mathrm{p} \leq 0.05$.

Table 5: Distribution of cytological findings in smokers group according to intensity of smoking.

\begin{tabular}{|lllllll|}
\hline $\begin{array}{l}\text { Cytological } \\
\text { findings }\end{array}$ & \multicolumn{2}{l}{ Cigarettes (Cigarette per day) } & \multicolumn{3}{l|}{ Water pipes (Bong per week) } \\
\hline & $\mathbf{1 - 4}$ & $\mathbf{5 - 1 4}$ & $\mathbf{1 4}$ & $\mathbf{1 - 3}$ & $\mathbf{4 - 6}$ & $\mathbf{6}$ \\
\hline Normal & - & $1(50 \%)$ & $13(68.4 \%)$ & $10(47.6 \%)$ & $12(100 \%)$ & $4(28.6 \%)$ \\
\hline Abnormal & $2(100 \%)$ & $1(50 \%)$ & $6(31.6 \%)$ & $11(52.4 \%)$ & $5(23.8 \%)$ & $8(57.1 \%)$ \\
\hline p-value & $0.01 *$ & & & $0.03 * *$ & & \\
\hline
\end{tabular}

*Statistically significant at $\mathrm{p} \leq 0.05, * *$ Statistically significant at $\mathrm{p} \leq 0.05$.

\section{DISCUSSION}

Cervical cancer killed up to 276,000 women in 2010 , about 64,000 were in developing countries. ${ }^{8}$ All metaanalyses and multi-institutional studies point out that smoking is an important cofactor for cervical squamous cancer. Some molecular mechanisms have been suggested how smoking may contribute to cervical carcinogenesis: one involves direct exposure of the deoxyribonucleic acid (DNA) in cervical epithelial cells to nicotine and cotinine, and the other involves exposure to the metabolic products resulting from the reactions of other components of cigarettes such as aromatic polycyclic hydrocarbons and aromatic amines. ${ }^{4} \mathrm{~A}$ controversial issue is becoming clear: smoking is certainly an independent risk factor for cervical cancer. A similar study conducted a pooled analysis of IARC multicentric case-control studies and showed that eversmokers had an excess risk of cervical cancer that persisted even after controlling for the stronger effect of HPV and for other potential cofactors in the progression from infection to cancer. ${ }^{9}$ In this study, authors demonstrated that smoking was associated with increasing cervical abnormalities in both colposcopical and cytological types. Many studies as Altabarani et al studied this correlation between smoking and colposcopical findings and reached to the same result as ours. ${ }^{10}$ In another study, El-Moselhy EA, et al focused on cytological findings and they found differences in abnormal pap smears rate between smokers and nonsmokers groups $(58.5 \%, 41.2 \%)$ respectively, which were similar to the results of this study. ${ }^{8}$ In agreement with the present study, Kyung-Jin-Min et al, found that smoking for a period exceeding ten years correspond to a higher percentage of abnormal cytological findings with pvalue $=0.013$ and this result is consistent with this study with p-value $=0.0411$. Furthermore, Roura $\mathrm{E}$ et al, reported that there was an important positive correlation between the cytological abnormalities and increasing in the number of cigarettes smoked daily with pvalue $=0.005$, authors found the same result in this study with $\mathrm{p}$-value $=0.0112$. The main weakness in this study that authors were unable to measure the exact levels of nicotine in the cervix, and the sample was limited to hospital reviews, so the authors recommend to carry out studies that measuring nicotine levels in the cervix and expanding the sample to include a larger segment of the population.

\section{CONCLUSION}

This study data showed an association between smoking and colposcopical and cytological abnormalities in the 
cervix uteri. This correlation is directly proportional to the increasing in the duration and intensity of smoking.

Funding: No funding sources Conflict of interest: None declared

Ethical approval: The study was approved by the Institutional Ethics Committee

\section{REFERENCES}

1. Sugawara Y, Tsuji I, Mizoue T, Inoue M, Sawada N, Matsuo K, et al. Cigarette smoking and cervical cancer risk: an evaluation based on a systematic review and meta-analysis among Japanese women. Japanese J Clin Oncol. 2018;49(1):1-10.

2. Bray F, Ferlay J, Soerjomataram I, Siegel R, Torre L, Jemal A, et al. Global cancer statistics 2018: GLOBOCAN estimates of incidence and mortality worldwide for 36 cancers in 185 countries. Ca Cancer J Clin. 2018;68:394-424.

3. Bruni L, Albero G, Serrano B, Mena M, Gómez D, Muñoz J, et al. ICO/IARC information centre on HPV and cancer (HPV information centre). Human Papillomavirus Related Dis Syria. 2019:1-69.

4. Fonseca-Moutinho JA. Smoking and cervical cancer. ISRN Obstet Gynecol. 2011;2011:847684.

5. Oh H, Kim M, Seo S, Lee J. Association of combined tobacco smoking and oral contraceptive use with cervical intraepithelial neoplasia 2 or 3 in Korean Women. J Epidemiol. 2016;26(1):22-9.

6. Zendehdel K. Water pipe smoking and genital wart: call for epidemiological research. Basic Clin Cancer Res. 2019;11(3):111-2.

7. Amtha R, Kurniadi A. An overview of oral mucosa condition of shisha smoker. J Dentomaxillofacial Sci. 2016;1(2):73-6.
8. El-Moselhy E, Salim S, Hagrass S. Prevalence and risk factors of cervical intraepithelial neoplasia and cervical cancer among ever married adult females in Egypt: a survey study. J Compr Cancer Res. 2017;1(1):100002.

9. Feng R, Ying Hu S, Hui Zhao F, Zhang R, Zhang X, Wallach A, et al. Role of active and passive smoking in high-risk human papillomavirus infection and cervical intraepithelial neoplasia grade 2 or worse. J Gynecol Oncol. 2017;28(5):e47.

10. AL-Tabarani S. The importance of colposcopy and cervical smear in the early diagnosis of cervical lesions. J Damascus University Med Sci. 2008;24(1):95-117.

11. Min K, Lee J, So K, Kim M. Association between passive smoking and the risk of cervical intraepithelial neoplasia 1 in Korean women. J Epidemiol. 2018;28(1):48-53.

12. Roura E, Castellsague X, Pawlita M, Travier N, Waterboer T , Margall N, et al. Smoking as a major risk factor for cervical cancer and pre-cancer: Results from the EPIC cohort. Int J Cancer. 2014;135:45366.

Cite this article as: Ali MA, Salman SK, Issa RM. The relation between active smoking and colposcopical and cytological findings in the cervix uteri. Int J Reprod Contracept Obstet Gynecol 2020;9:3179-82. 